The ${ }^{2} \mathrm{E} \rightarrow{ }^{4} \mathrm{~A}_{\underline{z}}$ Spectra of Hexaquochromium (III) Crystals ${ }^{*}$

F. Diomedi Camassei and Leslie S. Forster

Department of Chemistry, University of Arizona, Tucson, Arizona 85721

"Supported by the U.S. Atömic Energy Commissiom (COO-773 18)

\title{
LEGAT NOTICE
}

This report was prepared as an account of Government Anther United A. Makes any warranty or representation, expressed or of the Commission:

of any, completeness, or usefulness of the information contained ind, with respect to the accuof any information, apparatus, method, or proction contalned in this report, or that the

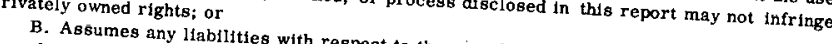

use of any information, apparatus, method, or proces's disclosed damages resulting from the As used in the above. "person acting on proces's disclosed in thls report.

ployee or contractor of the Commission, or behalf of the Commission" includes any emsuch employee or contractor of the disseminates, or provides accese commission, or employee of such contract extent that with the Commisston or access to, any information pursuant to his emportor prepares, 


\section{DISCLAIMER}

This report was prepared as an account of work sponsored by an agency of the United States Government. Neither the United States Government nor any agency Thereof, nor any of their employees, makes any warranty, express or implied, or assumes any legal liability or responsibility for the accuracy, completeness, or usefulness of any information, apparatus, product, or process disclosed, or represents that its use would not infringe privately owned rights. Reference herein to any specific commercial product, process, or service by trade name, trademark, manufacturer, or otherwise does not necessarily constitute or imply its endorsement, recommendation, or favoring by the United States Government or any agency thereof. The views and opinions of authors expressed herein do not necessarily state or reflect those of the United States Government or any agency thereof. 


\section{DISCLAIMER}

Portions of this document may be illegible in electronic image products. Images are produced from the best available original document. 
Running Head

Spectra of Hexaquochromium (III) Crystals

Proofs to: Leslie S. Forster

Address: Until June 15, 1969

Department of Chemistry

The Weizmann Institute of Science

Rehovoth, Israel

After June 15, 1969

Department of Chemistry

- University of Arizona

Tucson, Arizona 


\section{Abstract}

The emission spectra of $\mathrm{C}\left(\mathrm{NH}_{2}\right)_{3} \mathrm{Al}\left(\mathrm{SO}_{4}\right)_{2} \cdot 6 \mathrm{H}_{2} \mathrm{O}(\mathrm{CASH})$, $\mathrm{C}\left(\mathrm{NH}_{2}\right)_{3} \mathrm{Al}\left(\mathrm{SO}_{4}\right)_{2} \cdot 6 \mathrm{D}_{2} \mathrm{O}(\mathrm{GASD}), \mathrm{AlCl}_{3} \cdot 6 \mathrm{H}_{2} \mathrm{O}$, and $\mathrm{AlCl}_{3} \cdot 6 \mathrm{D}_{2} \mathrm{O}$ doped with $\mathrm{Cr}^{3^{+}}$have been recorded at 4 and $77^{\circ} \mathrm{K}$. The two $\underline{\mathrm{R}}$ lines are intense in both the 4 and $77^{\circ} \mathrm{K}$ spectra of $\mathrm{Cr}^{3^{+}}$: GASH and $\mathrm{Cr}^{\mathrm{s}^{+}}$: GASD, negating an interpretation in which the $\underline{R}$ lines are ascribed to the components of ${ }^{2} E \leftarrow{ }^{4} A_{2}$ from a single species.

The vibronic intervals within $350 \mathrm{~cm}^{-1}$ of the origin are only slightly changed when $\mathrm{H}_{2} \mathrm{O}$ is replaced by $\mathrm{D}_{2} \mathrm{O}$, whereas the energies of most vibrations in the $400-1000 \mathrm{~cm}^{-1}$ range are much reduced by deuteration. 


\section{INTRODUCTION}

The ${ }^{2} E \leftarrow{ }^{4} A_{2}$ absorption spectra of hexaquochromium (III) ions in the crystalline hosts $\mathrm{C}\left(\mathrm{NH}_{2}\right)_{3} \mathrm{Al}\left(\mathrm{SO}_{4}\right)_{2} \cdot 6 \mathrm{H}_{2} \mathrm{O}(\mathrm{GASH})$ and $\mathrm{AlCl}_{3} \cdot 6 \mathrm{H}_{2} \mathrm{O}$ have been described in some detail (1, 2). The two strong absorption lines in the pure. $\mathrm{GCrSH}$... spectrum were assigred to the split components of ${ }^{2} \mathrm{E} \leftarrow{ }^{4} A_{2}$ (R lines), in conflict with the interpretation of Martin-Brunetière ard Couture wherein these lines were ascribed to the unsplit ${ }^{2} E_{5}{ }^{3} A_{2}$

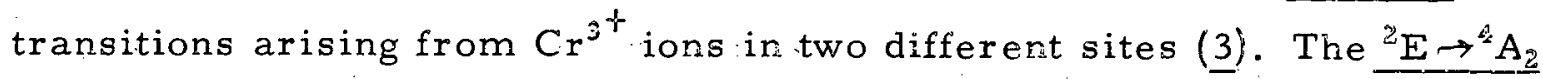
emission, which is weak but detectable in $\mathrm{Cr}^{3^{+}}: \mathrm{GASH}$, is much more intense in the $\mathrm{D}_{2} \mathrm{O}$ analog, $\mathrm{Cr}^{3^{+}}$:GASD (4). One purpose of the present work is the resolution of the aformementioned conflict.

The ${ }^{2} \mathrm{E} \rightarrow{ }^{4} \mathrm{~A}_{\mathrm{E}}$ emission from $\mathrm{Cr}^{3}{ }^{+\mathrm{r}}: \mathrm{KAl}\left(\mathrm{SO}_{4}\right)_{2} \cdot 12 \mathrm{D}_{2} \mathrm{O}$ has been reported but no vibronic analysis was attempted (므). The second aim of this study is to consider the effect of deuteration and environment on the vibronic transitions of the $\mathrm{Cr}\left(\mathrm{H}_{2} \mathrm{O}\right)_{6}{ }^{{ }^{+}}$moiety. Preliminary vibronic as ignments

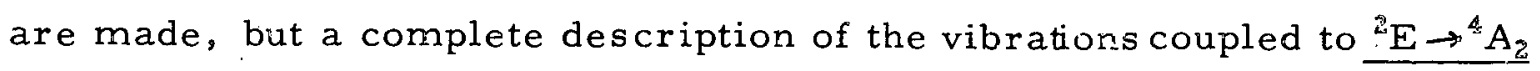
is not yet possible.

\section{EXPERIMENTAL}

Doped (10\%) crystals of $\mathrm{Cr}^{3^{+}}$:GASH were obtained by evaporation of aqueous solutions containing guanidine, aluminium, and chromium sulfates in the appropriate mole ratios. The $\mathrm{Cr}^{3+}$ :GASD was prepared by dissolving $\mathrm{Cr}^{3^{+}}$:GASH in $\mathrm{D}_{2} \mathrm{O}$ and removing the solvent. At least two such exchanges were performed. The $\mathrm{Cr}^{3^{+}}: \mathrm{AlCl}_{\hat{3}} \cdot 6 \mathrm{H}_{2} \mathrm{O}$ was obtained by saturating an aqueous solution of aluminium chloride and blue-gray chromium chloride 
with gaseous $\mathrm{HCl}$ at $15^{\circ}$. The $\mathrm{D}_{2} \mathrm{O}$ analog was prepared in a like fashion; $\mathrm{DCl}$ was generated by the reaction of $\mathrm{POCl}_{3}$ and $\mathrm{D}_{2} \mathrm{O}$.

Emission spectra were recorded on Kodak $I-N$ plates with a grating, spectrograph $(90 \AA / \mathrm{mm})$. Calibration was made with a neon discharge lamp and the sharp line positions were determined both with a recording microdensitometer and visually with a travelling microscope. In all cases the samples were immersed directly in the coolant and the emission was excited by radiation from a.500 W Hg lamp, filtered through 9782 and 3387 Corning glasses and a short pass:interference filter rejecting radiation. $>610 \mathrm{~m} \mu$. The luminescence passed through a Corning 2403 filter before entering the spectrograph. Prolonged exposure of $\mathrm{Cr}^{3^{+}}: \mathrm{GASH}$ to the $\mathrm{Hg} \operatorname{lamp}$ produced an impurity which emitted a spurious sharp doublet at about $6915 \AA$.

\section{RESULTS}

$\mathrm{Cr}^{3^{+}}:$GASH and $\mathrm{Cr}^{3^{+}}:$GASD

The $4^{\circ} \mathrm{K}$ emission spectra are displayed in Figs. 1 and 2. Except for a shift of $5 \mathrm{~cm}^{-1}$ to lower energy, broadening, and the appearance of hot bands, the $77^{\circ} \mathrm{K}$ spectra closely resemble those at $4^{\circ} \mathrm{K}$. In particular, the intensities of both $\underline{R}$ lines are nearly the same at each temperature. In pure $\mathrm{GCrSH}$, the $\underline{\mathrm{R}}$ lines occur in absorption at 14133 and $14114 \mathrm{~cm}^{-1}$, but upon dilution to $50 \% \mathrm{Cr}^{3^{+}}$:GASH, these lines shift to 14108 and $14092 \mathrm{~cm}^{-1}$ (1). In the $4^{\circ} \mathrm{K}$ emission from $10 \% \mathrm{Cr}^{3^{+}}$:GASH, the intense lines are located at 14109 and $14092 \mathrm{~cm}^{-1}$. The close coincidence between these lines in absorption and emission confirms the assignment as the $\mathrm{O}-\mathrm{O}$ transitions. 
If a Boltzmann distribution (thermalization) obtains between the ${ }^{2} \mathrm{E}$ components, emission from the higher energy component will be quenched at sufficiently low, temperatures. A large number of ${ }^{2} \mathrm{E} \rightarrow{ }^{4} \mathrm{~A}_{2}$ emission spectra have been recorded and in no case has nonthermalization between ${ }^{2} \mathrm{E}$ components been observed. The persistence of two intense $\underline{R}$ lines, separated by $17 \mathrm{~cm}^{-1}$, at $4^{\circ} \mathrm{K}$, provides strong support for the two site interpretation of the $\mathrm{Cr}^{3^{t}}$ :GASH spectrum (3).

The $\mathrm{O}-\mathrm{O}$ lines are shifted $13 \mathrm{~cm}^{-1}$ to the red when $\mathrm{H}_{2} \mathrm{O}$ is replaced by $\mathrm{D}_{2} \mathrm{O}$ and the splitting is reduced by about $1 \mathrm{~cm}^{-1}$.

As indicated above, the O-O doublet cannot be ascribed to the ${ }^{2} E$ splitting but rather results from complexes at different symmetry sites, $\underline{C_{3}}$ and $\underline{C}_{3 i}$. The apparent absence of the doubling in some of the vibronic bands $\underline{\text { e.g. }}, 13888 \mathrm{~cm}^{-1}$, is unexpected. It is reasonable that the vibrations be coupled to ${ }^{2} \mathrm{E} \rightarrow{ }^{4} \mathrm{~A}_{2}$ in both environments, and in fact this ray be the case, with one component somewhat weaker and hidden in the broad vibronic bands.

Two weak lines appear at O-O-2198 and O-O-2283 $\mathrm{cm}^{-1}$ in the $\mathrm{Cr}^{3^{+}}$: GASD emission spectrum.

$\mathrm{Cr}^{3^{+}}: \mathrm{AlCl}_{3}: 6 \mathrm{H}_{2} \mathrm{O}$ and $\mathrm{Cr}^{3^{+}}: \mathrm{AlCl}_{3} \cdot 6 \mathrm{D}_{2} \mathrm{O}$

The $4^{\circ} \mathrm{K}$ emission spectra are shown in Figs. 3 and 4 . The O-O lines are unsplit and the $14555 \mathrm{~cm}^{-1}$ line in $\mathrm{Cr}^{3+}: \mathrm{AlCl}_{3} \cdot 6 \mathrm{H}_{2} \mathrm{O}$ coincides, within $7 \mathrm{~cm}^{-1}$, with the apparent ${ }^{2} \mathrm{E} \rightarrow{ }^{4} \mathrm{~A}_{2}$ origin of pure $\mathrm{CrCl}_{3} \cdot 6 \mathrm{H}_{2} \mathrm{O}$ (Fig. 5), 
confirming the assignment of the origin (1). The temperature effect is about the same as in $\mathrm{Cr}^{3^{+}}: \mathrm{GASD}$, a shift of $6 \mathrm{~cm}^{-1}$. to lower energy as the temperature is increased from $4^{\circ}$ to $77^{\circ} \mathrm{K}$. The deuteration shift is in the opposite direction of that in GASH, viz. $5 \mathrm{~cm}^{-1}$ to the blue when $\mathrm{H}_{2} \mathrm{O}$ is replaced by $D_{2} \mathrm{O}$. The weak lines at O-O-2253, O-O-2297, and O-O $2320 \mathrm{~cm}^{-1}$ in $\mathrm{Cr}^{3^{+}}: \mathrm{AlCl}_{3} \cdot 6 \mathrm{D}_{2} \mathrm{O}$ are barely detectable in $\mathrm{Cr}^{3^{4}}: \mathrm{AlCl}_{3} \cdot 6 \mathrm{H}_{2} \mathrm{O}$, but are definitely shifted to the region of $\mathrm{O}-\mathrm{O}-3000 \mathrm{~cm}^{-1}$.

\section{DISCUSSION}

\section{$\mathrm{R}$ Lines in GASH}

The rejection of the two-site interpretation and the assignment of the 14109 and $14092 \mathrm{~cm}^{-1}$ lines to the components of ${ }^{2} \mathrm{E} \leftarrow{ }^{4} \mathrm{~A}_{2}$ was made on the basis of a simple axial ligand field model (1). In this model the ${ }^{4} \mathrm{~T}_{2}$ splitting, as measured by the separation of the band maxima of ${ }^{4} \mathrm{~A}_{1}\left({ }^{4} \mathrm{~T}_{2}\right) \leftarrow{ }^{4} \mathrm{~A}_{2}$ and ${ }^{4} \mathrm{E}\left({ }^{4} \mathrm{~T}_{2}\right) \leftarrow{ }^{4} \mathrm{~A}_{2}$, and the ${ }^{2} \mathrm{E}$ splitting are both proportional to the same trigonal field parameter, $\underline{\mathrm{v}}(6)$. From the ${ }^{4} \mathrm{~T}_{2} \leftarrow{ }^{4} \mathrm{~A}_{2}$ band splitting at $20^{\circ} \mathrm{K}, \underline{\mathrm{v}}$ is estimated as $640 \mathrm{~cm}^{-1}$ (1). The Sugano and Tanabe expresision (7) for the ${ }^{2} E$ splitting, $\lambda=-4 / 3 \underline{v} \mathcal{Y} /\left[\underline{W\left({ }^{2} E\right)-W\left({ }^{2} T_{2}\right)}\right]$, is nearly correct () and when $\underline{v}=640 \mathrm{~cm}^{-1} \mathrm{a}^{2} \underline{\mathrm{E}}$ splitting of some $20 \mathrm{~cm}^{-1}$ is computed for any reasonable value of the spin-orbit coupling constant, 9 . That the actual splitting for an ion in a given site is less than one $\mathrm{cm}^{-1}$ illustrates the inadequacy of a model in which a single $\underline{v}$ parameter describes both the ${ }^{2} \mathrm{E}$ and ${ }^{4} \underline{T}_{2}$ splittings. These splittings are not in general, related by a simple proportionality (9), but it is 
noteworthy that in $\mathrm{Cr}^{3^{+}}: \mathrm{AlCl}_{3} \cdot 6 \mathrm{H}_{2} \mathrm{O}$, both ${ }^{4} \mathrm{~T}_{2}$ ard $\underline{{ }^{2} \mathrm{E}}$ are unsplit (1) $)$.

Vibronic Assignments

The analysis of Nakagawa and Shimanouchi provides a useful basis for this discussion (10). The 51 normal modes of $\mathrm{M}\left(\mathrm{H}_{2} \mathrm{O}\right)_{6}$ complexes. in $\mathrm{T}_{\mathrm{h}}$ symmetry are classified as $\mathrm{a}_{\mathrm{g}}(3), \mathrm{a}_{\mathrm{u}}(1), \mathrm{e}_{\mathrm{g}}(3), \mathrm{e}_{\mathrm{u}}(1), \mathrm{t}_{\mathrm{g}}(5)$, and

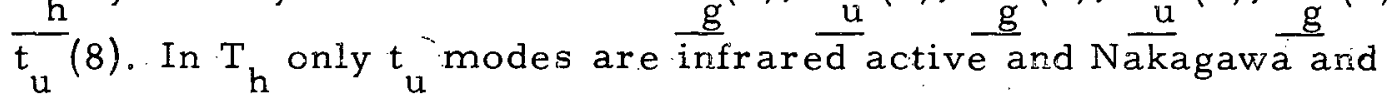

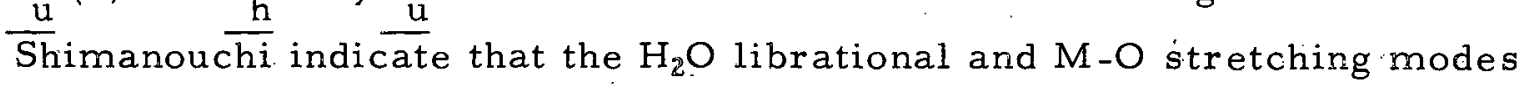
should appear in the $270-1000 \mathrm{~cm}^{-1}$ region while O-M-O deformation should lie below $250 \mathrm{~cm}^{-1}$. The $\mathrm{M}-\mathrm{O}$ and $\mathrm{O}-\mathrm{M}-\mathrm{O}$ frequencies will not be changed very much when $\mathrm{H}_{2} \mathrm{O}$ is replaced by $\mathrm{D}_{2} \mathrm{O}$, but the water librational energies are very sensitive to deuteration. For example, the $541 \mathrm{~cm}^{-1}$ transition in $\mathrm{Zn}\left(\mathrm{H}_{2} \mathrm{O}\right)_{6}^{3^{+}}$is found at $392 \mathrm{~cm}^{-1}$ in $\mathrm{Zn}\left(\mathrm{D}_{2} \mathrm{O}\right)_{6}^{3+}(10)$. The ratio of librational energies, $\nu\left(\mathrm{H}_{2} \mathrm{O}\right) / \nu\left(\mathrm{D}_{2} \mathrm{O}\right)$, ranges from 1.2 to $1.4(\underline{10}, \underline{11})$.

Comparison of the emission spectra of each $\mathrm{H}_{2} \mathrm{O}-\mathrm{D}_{2} \mathrm{O}$ pair (Figs. 1 and 2; Figs 3 and 4) permits the classification of the participating vibrations into deuterium-sensitive and deuterium-insensitive types. The low-frequency modes (within $350 \mathrm{~cm}^{-1}$ of the origin) fall. into the deuterium-insensitive category, while most of the higher-frequency vibrations are sensitive to deuteration with $\nu_{\mathrm{H}_{2} \mathrm{O}} / \nu_{\mathrm{D}_{2} \mathrm{O}}$ of $1.3-1.4$ Table 1).

In $\mathrm{AlCl}_{3} \cdot 6 \mathrm{H}_{2} \mathrm{O}$, and $\mathrm{CrCl}_{3} \cdot 6 \mathrm{H}_{2} \mathrm{O}$, the site symmetry of the trivalent ion is $\mathrm{C}_{3 i}(12)$. Upon reduction of the symmetry from $\mathrm{T}_{\mathrm{h}}$ to $\mathrm{C}_{3 \mathrm{i}}$ only the 
$\mathrm{t}_{\mathrm{u}}$ and $\mathrm{t}_{\mathrm{g}}$ modes are split into two components. In the $\mathrm{Cr}^{3^{4}}: \mathrm{AlCl}_{3} \cdot 6 \mathrm{H}_{2} \mathrm{O}$ and $\mathrm{Cr}^{3^{4}}: \mathrm{AlCl}_{3} .6 \mathrm{D}_{2} \mathrm{O}$ spectra where the lines are narrow, the results of this splitting are evident (Figs. 3 and 4). Upor exchange of $\mathrm{D}_{2} \mathrm{O}$ for $\mathrm{H}_{2} \mathrm{O}$, not only are the energies but the splitting patterns of vibronic transitions involving low energy $\left(<350 \mathrm{~cm}^{-1}\right)$ vibrations are the same, and the correlation of these vibrations in the two systems is evident. The correspondence of the deuterium-sersitive bands is less obvious and the correlations in Table I are only suggestive. $\wedge^{I R}$ spectrum of $\mathrm{CrCl}_{3} .6 \mathrm{H}_{2} \mathrm{O}$ have been assigned: $800 \mathrm{~cm}^{-1}, \mathrm{H}_{2} \mathrm{O}$ rock; $541 \mathrm{~cm}^{-1}, \mathrm{H}_{2} \mathrm{O}$ wag; and $490 \mathrm{~cm}^{-1} \cdot \mathrm{M}-\mathrm{O}$ stretch (10). The se can also be identified in the $\mathrm{Cr}^{3^{+}}: \mathrm{AlCl}_{3} \cdot 6 \mathrm{H}_{2} \mathrm{O}$ emission spectrum. The weak infrared band at $\sim 370 \mathrm{~cm}^{-1}$ has not been assigned, the $364 \mathrm{~cm}^{-2}$ shoulder may be the courterpart in the emission spectrum. The M-O stretch frequency should not be changed much by deuteration and the $476 \mathrm{~cm}^{-1}\left(\mathrm{AlCl}_{3} \cdot 6 \mathrm{H}_{2} \mathrm{O}\right)$ and $491 \mathrm{~cm}^{-1}\left(\mathrm{AlCl}_{3}, 6 \mathrm{D}_{2} \mathrm{O}\right)$ lines may arise from this vibration.

In a like manner, the spectra of $\mathrm{Cr}^{3^{+}}: \mathrm{GASH}$ and $\mathrm{Cr}^{3^{+}}$:GASD are analyzed. A one-to-one correspondence can be madefor the low frequency modes $\left(<350 \mathrm{~cm}^{-1}\right)$ which are deuterium-insensitive, but the correlations of the high frequency deuterium-sensitive vibration are again uncertair.

The absorption spectra of $\mathrm{GCrSH}(1)$ and $\mathrm{CrCl}_{3} \cdot 6 \mathrm{H}_{2} \mathrm{O}$ (Fig. 5) have been determined at $20^{\circ} \mathrm{K}$. A number of the prominent vibrations are found in both the absorption and emission spectra. A possible correlation between the intervals in the several hosts is presented in Table I. The $\mathrm{Cr}^{3^{+}}$:GASH absorption and emission spectra are more nearly mirror images than is sometimes the case (13) but there are some notable 
differences. For example, the $\mathrm{Cr}^{3^{+}}$:GASH $329 \mathrm{~cm}^{-1}$ vibration is relatively more intense in absorption than in emission.

If we compare the ${ }^{2} \mathrm{E} \rightarrow \mathrm{A}^{4} \mathrm{~A}_{2}$ emission spectra of $\mathrm{Cr}^{3^{+}}$in $\mathrm{GASD}, \mathrm{AlCl}_{3}$. $6 \mathrm{D}_{2} \mathrm{O}$, and $\mathrm{KAl}\left(\mathrm{SO}_{4}\right)_{2} \cdot 12 \mathrm{D}_{2} \mathrm{O}(\underline{5})$, some similarities as well as some differences are noticable. In all three hosts there is a strong band around $200 \mathrm{~cm}^{-1}$, which is not much shifted by deuteration. By assuming an analogous small deuterium shift in all hosts, the $273 \mathrm{~cm}^{-1} \cdot\left(\mathrm{AlCl}_{3} \cdot 6 \mathrm{D}_{2} \mathrm{O}\right)$ and $306 \mathrm{~cm}^{-1}$ (GASD) bands can be correlated. These in turn probably correspond to the $307 \mathrm{~cm}^{-1}$ vibration in $\mathrm{KAl}\left(\mathrm{SO}_{4}\right)_{2} \cdot 12 \mathrm{D}_{2} \mathrm{O}$. The 550 and $674 \mathrm{~cm}^{-1} \mathrm{KAl}\left(\mathrm{SO}_{4}\right)_{2} \cdot 12 \mathrm{D}_{2} \mathrm{O}$ bands are also present in the GASD and $\mathrm{AlCl}_{3}$. $6 \mathrm{D}_{2} \mathrm{O}$ spectra. The markedly different intensity distribution in the emission spectra are apparent. The ratio of the $\underline{R}$ line intensity to the total intensity $\left(\eta_{R}\right)$ is a measure of the "allowedness" of the transition (14). The ${ }^{2} E \rightarrow{ }^{n} A_{2}$ $\underline{\mathrm{R}}$ Fine in $\mathrm{Cr}^{3^{+}}: \mathrm{AlCl}_{3} \cdot 6 \mathrm{H}_{2} \mathrm{O}$ is magnetic dipole, but the nature of the transition in $\mathrm{Cr}^{3^{+}}$:GASH is uncertain (1). The $\eta_{\mathrm{R}}$ values are 0.07 and 0.27 ir $\mathrm{Cr}^{34}$ : $\mathrm{AlCl}_{3} .6 \mathrm{D}_{2} \mathrm{O}$ and $\mathrm{Cr}^{3^{+}}: \mathrm{GASD}$, respectively (4), indicating a much greater contribution of vibrationally induced intensity in the former. The intensities of vibrationally induced components will be more sersitive to environment than those of "allowed" components.

In addition to the different intensity distributions, there is a ignificant difference between the $\mathrm{Cr}^{3^{+}}$:GASD and $\mathrm{Cr}^{3^{+}}: A 1 C 1_{3} . \mathrm{D}_{2} \mathrm{O}$ spectra, viz ${ }_{2}$, ar additional deuterium-insensitive band is observed in $\mathrm{Cr}^{3+}: \mathrm{AlCl}_{3} \cdot 6 \mathrm{D}_{2} \mathrm{O}$. It is conceivable that the 169 and $121 \mathrm{~cm}^{-1} \mathrm{Cr}^{3^{+}}: \mathrm{AlCl}_{3} \cdot 6 \mathrm{D}_{2} \mathrm{O}$ bands are components of the $141 \mathrm{~cm}^{-1}$ GASD transition, but the IR and Raman spectra of $\mathrm{CrCl}_{3}, 6 \mathrm{D}_{2} \mathrm{O}, \mathrm{GCrSH}$ and $\mathrm{GCrSD}$ will be required to settle this question ard 
to make more definitive assignments. Inasmuch as we are interested in the intramolecular $\mathrm{Cr}\left(\mathrm{H}_{2} \mathrm{O}\right)_{6}^{3^{+}}$and $\mathrm{Cr}\left(\mathrm{D}_{2} \mathrm{O}\right)_{6}^{3^{+}}$modes, the vibrational spectra of the host crystals are not sufficient for this purpose.

The data.in Table I qualitatively support the conclusions of Nakagawa and Shimanouchi (10). The O-M-O deformations fall below $350 \mathrm{~cm}^{-1}$ and the bulk of the vibrations in the $350-1000 \mathrm{~cm}^{-1}$ region are deuterium shifted and consequently water librations. The weak bands near $3000 \mathrm{~cm}^{-1}\left(\mathrm{H}_{2} \mathrm{O}\right)$ and $2200 \mathrm{~cm}^{-1}\left(\mathrm{D}_{2} \mathrm{O}\right)$ are the localized water stretching modes. The vibrations below $100 \mathrm{~cm}^{-1}$ may be lattice modes, but a vibration around $50 \mathrm{~cm}^{-1}$ is found in five different hosts, suggesting an intramolecular assignment. 
Legends

Fig. 1. ${ }^{2} \mathrm{E} \rightarrow^{4} \mathrm{~A}_{2}$ emission spectrum of $10 \% \mathrm{Cr}^{3^{+}}: \mathrm{GASH}$ at $4^{\circ} \mathrm{K}$ 。

Fig. 2. ${ }^{2} \mathrm{E} \rightarrow \rightarrow^{4} \mathrm{~A}_{2}$ emission spectrum of $10 \% \mathrm{Cr}^{3+}$ : GASD at $4^{\circ} \mathrm{K}$. Curve (b) was taken with a long exposure. Two weak bands at 11899 and $11814 \mathrm{~cm}^{-1}$ are not shown.

:Fig. 3. ${ }^{2} \mathrm{E} \rightarrow{ }^{4} \mathrm{~A}_{2}$ emission spectrum of $10 \% \mathrm{Cr}^{3+}: \mathrm{AlCl}_{3} \cdot 6 \mathrm{H}_{2} \mathrm{O}$ at $4^{\circ} \mathrm{K}$. A weak feature near $11500 \mathrm{~cm}^{-1}$, is not shown.

Fig. 4. ${ }^{2} \mathrm{E} \rightarrow \rightarrow^{4} \mathrm{~A}_{2}$ emission spectrum of $10 \% \mathrm{Cr}^{3 t}: \mathrm{AlCl}_{3} \cdot 6 \mathrm{D}_{2} \mathrm{O}$ at $4^{\circ} \mathrm{K}$. Weak lines at 12307,11263 , and $11.240 \mathrm{~cm}^{-1}$ are not shown.

Fig. 5. ${ }^{2} \mathrm{E}^{t^{4}} \mathrm{~A}_{2}$ absorption spectrum of $\mathrm{CrCl}_{3} \cdot 6 \mathrm{H}_{2} \mathrm{O}$ (redrawn from ref. (2)). The polariszations are referred to the crystal $\underline{c}$ axis. 
Table I. Correlation of $\underline{{ }^{2} \mathrm{E} \rightarrow{ }^{2} A_{2}}$ Vibrations $\left(\mathrm{cm}^{-1}\right)$

$$
\mathrm{AlCl}_{3} \cdot 6 \mathrm{H}_{2} \mathrm{O} \quad \mathrm{AlCl}_{3} \cdot 6 \mathrm{D}_{2} \mathrm{O} \quad \mathrm{GASH} \quad \mathrm{GASD} \quad \mathrm{KAl}\left(\mathrm{SO}_{4}\right)_{2} \cdot 12 \mathrm{D}_{2} \mathrm{O}
$$

Emission Absorption ${ }^{\mathrm{a}}$ I.R. ${ }^{\mathrm{b}}$ Emission, Emission. Absorption ${ }^{\mathrm{c}}$ Errission Emission ${ }^{\mathrm{d}}$

\begin{tabular}{|c|c|c|c|c|c|c|c|}
\hline 46 & 44 & & $37-62$ & 51 & $40-60$ & 49 & \\
\hline 82 & 89 & & 82 & & & & \\
\hline \multirow[t]{2}{*}{122} & 123 & & 121 & & & & \\
\hline & & & & 144 & 151 & 141 & \\
\hline $160+173$ & 166 & & $155+169$ & & & & \\
\hline 219 & 219 & & 214 & 214 & 204 & 209 & 188 \\
\hline 253 & 256 & & & 254 & 254 & 248 & \\
\hline 293 & 298 & & 273 & 329 & 333 & 306 & 307 \\
\hline 444 & 450 & & & 445 & 450 & & \\
\hline 476 & 484 & 490 & 491 & 479 & 489 & 490 & \\
\hline $544+570$ & 558 & 541 & $393+408$ & 569 & 566 & 415 & \\
\hline $614+628$ & 629 & & $445+459$ & $606+641$ & 626 & 452 & \\
\hline 692 & 677 & & $517+537$ & 667 & & 518 & \\
\hline 731 & 731 & & & 714 & 716 & & \\
\hline 769 & 778 & & 564 & 769 & 756 & 547 & 550 \\
\hline 817 & 825 & 800 & $608+627$ & 797 & & 574 & \\
\hline 885 & & & 672 & & & 673 & 674 \\
\hline 951 & & & 725 & & & 732 & \\
\hline
\end{tabular}
a. $\mathrm{CrCl}_{3} \cdot 6 \mathrm{H}_{2} \mathrm{O}$ (fig. 5)
b. $\mathrm{CrCl}_{3} \cdot 6 \mathrm{H}_{2} \mathrm{O}$, ref. (10)
c. $\mathrm{GCrSH}$, ref. (2)
d. ref. (ㅁ) 


\section{References}

1. R. L. Carlin and I. M. Walker, J.Chem.Phys. 46, 3921 (1967).

2. I. M. Walker, Ph.D. Thesis, Brown University, 1967.

3. F. Martin-Brunetière and L. Couture, Compt. Rend. 256, 5327 (1963).

4. F. Diomedi Camassei and I.S. Forster, J.Chem. Phys.

5. G.J. Goldsmith, F.V. Shallcross, and D.S. McClure, J.Mol.Spectry. 16,296 (1965).

6. R. M. McFarlane, J.Chem. Phys. 39, 3118 (1963).

7. S. Sugano and Y. Tánabe, J.Phys.Soc. Japan 13, 880 (1958).

8. R. M. McFarlane, J.Chem. Phys. 47, 2066 (1967).

9. Y. Kawasaki and L.S. Forster, J. Chem. Phys.

10. I. Nakagawa and T. Shimanouchi, Śpectrochim. Acta 20, 429 (1964).

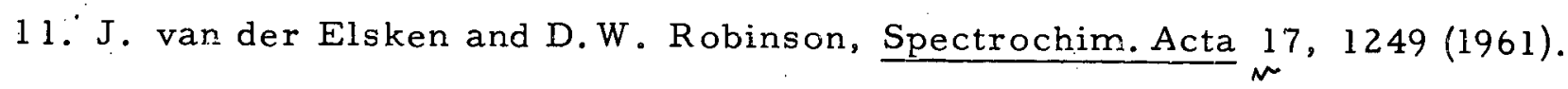

12. K.R. Andress and C. Carpenter, Z Krist. A87, 446 (1934).

13. R. A. Condrate and L.S. Forster, J.Mol.Spectry. 24, 490 (1967).

14. A. Albrecht, J.Chem. Phys. 33, 156 (1960). 


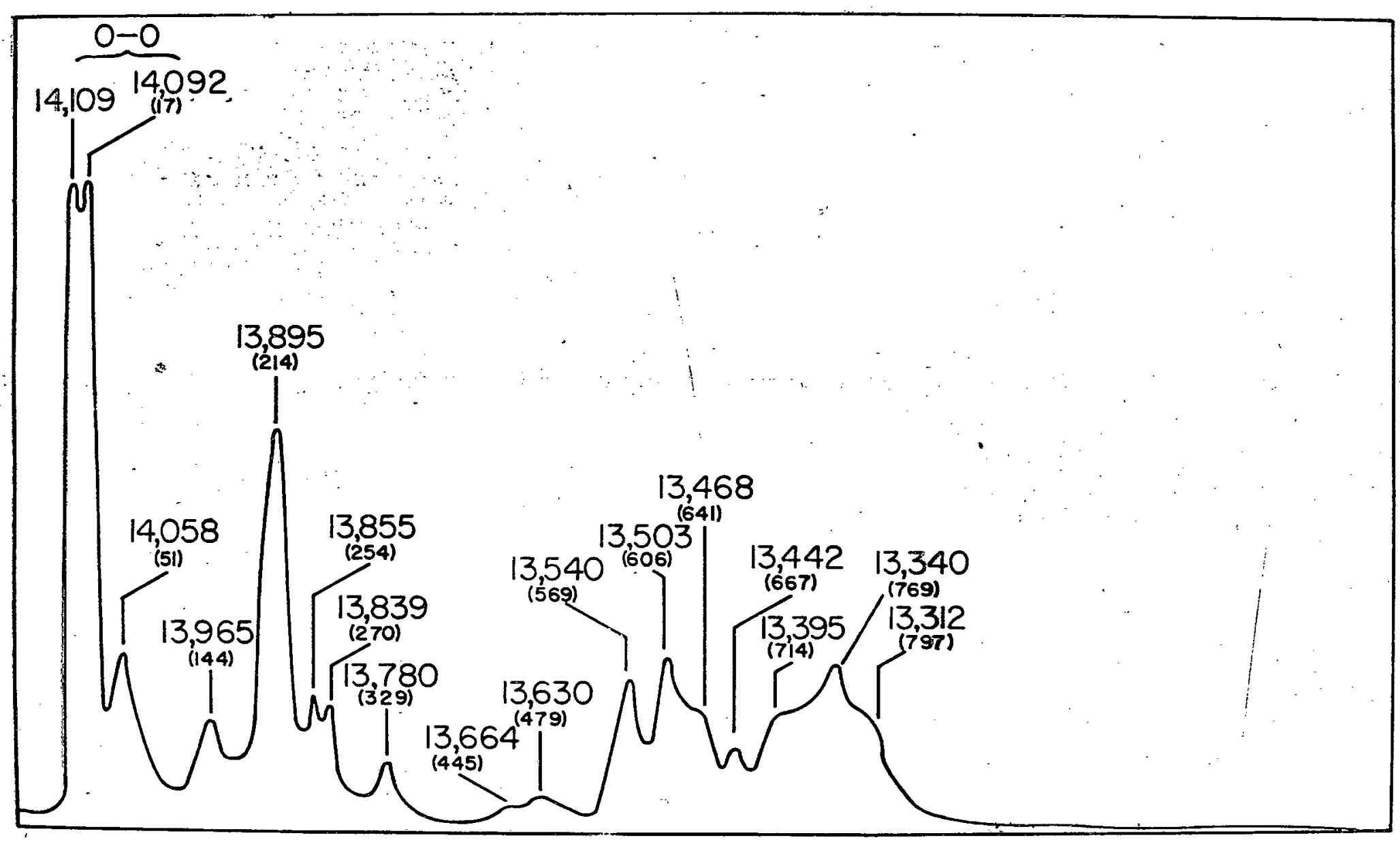




\section{$7 y_{2} 2$}

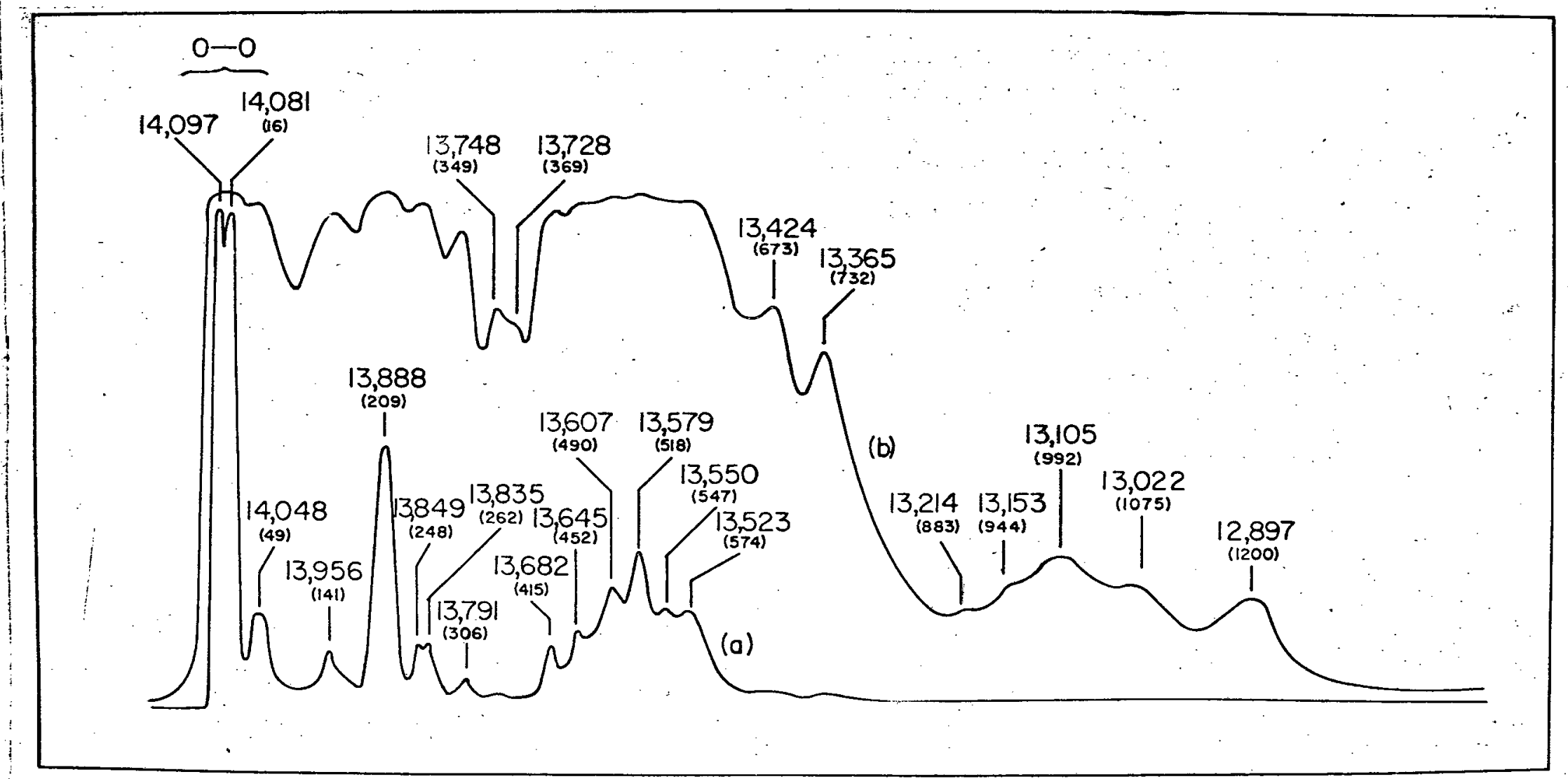



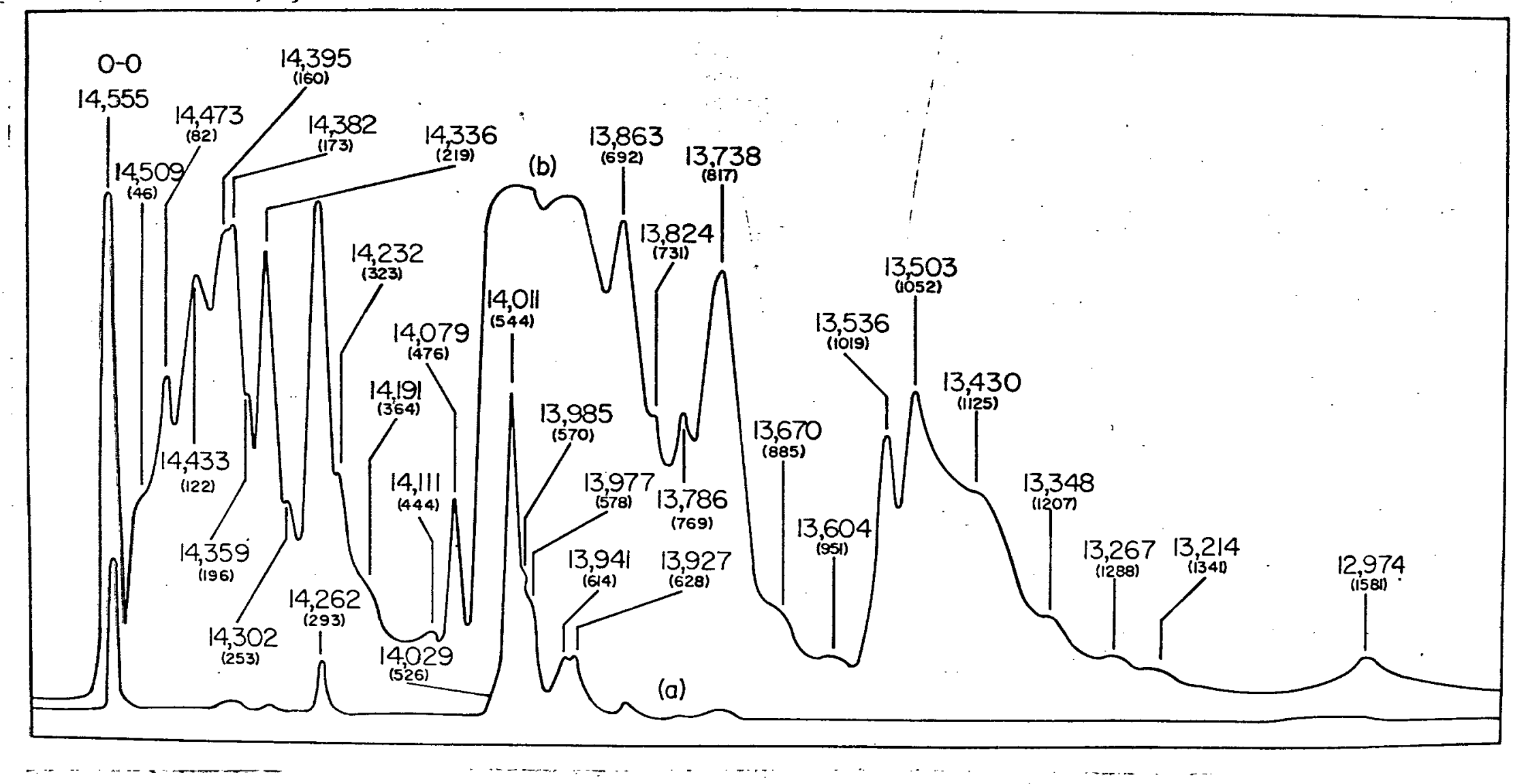


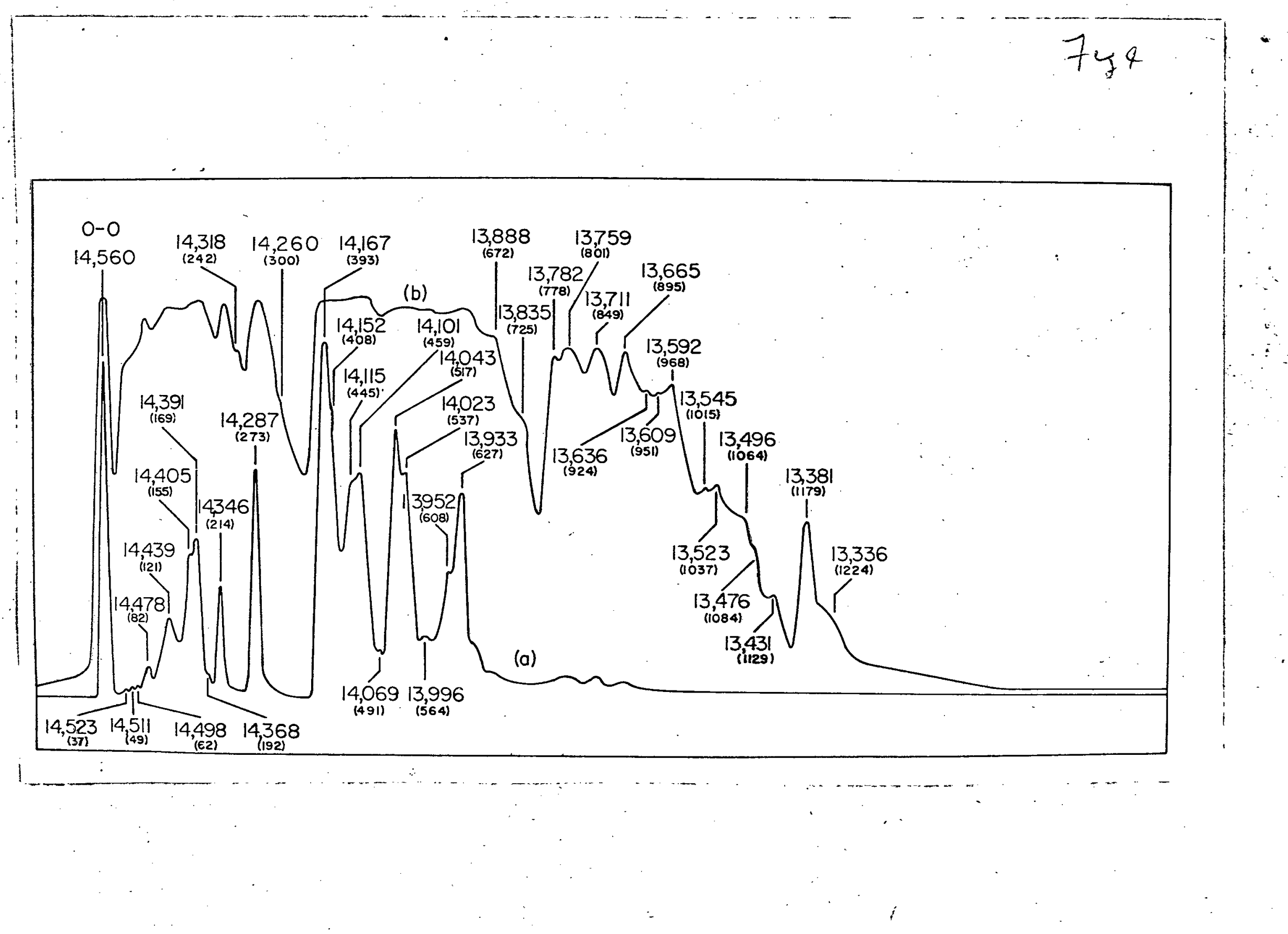




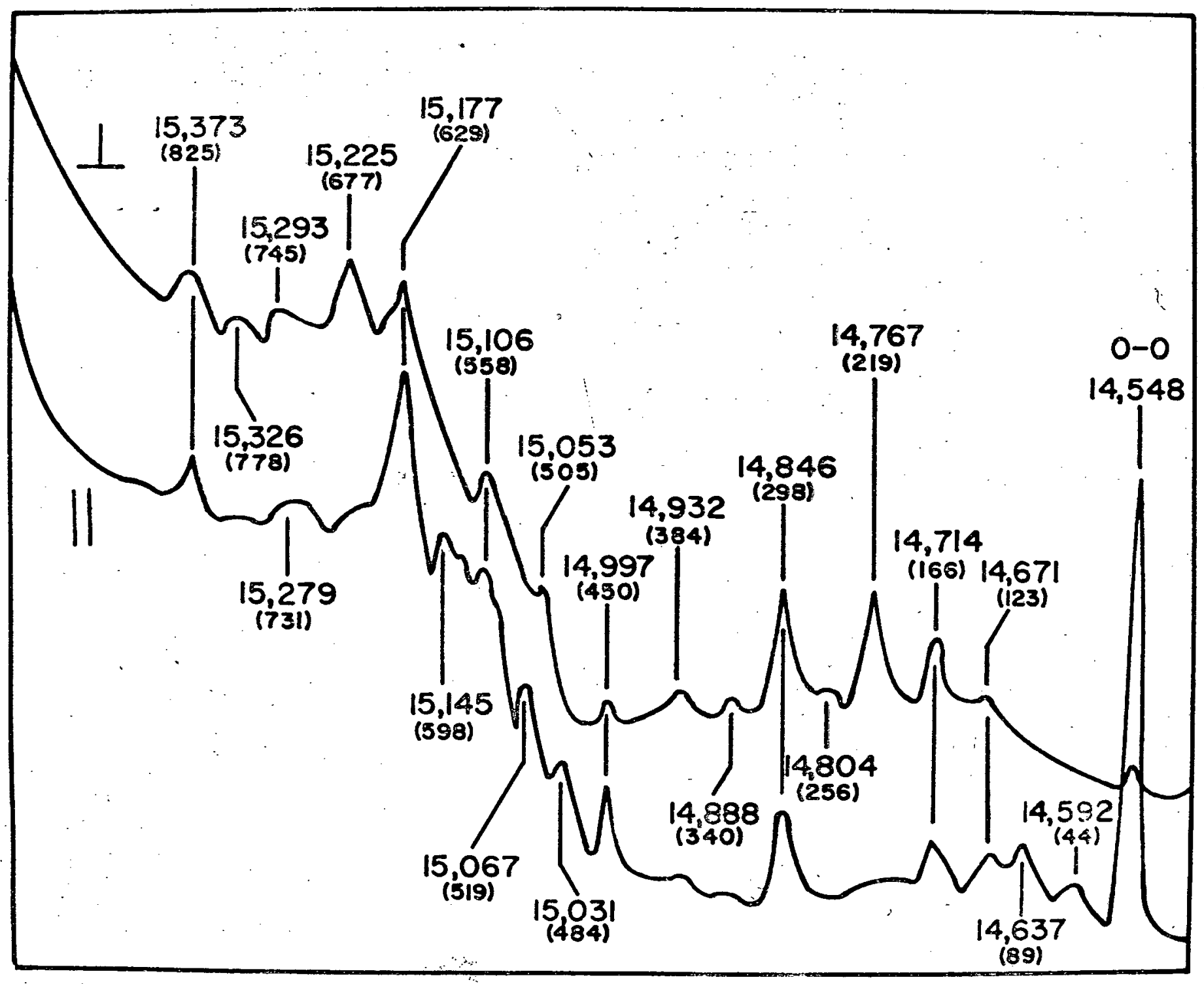

